\title{
Lembaga Dakwah dan Wasatiyah: Sebuah Tela'ah Perspektif Manajemen Dakwah di Kota Salatiga
}

\author{
Yahya \\ Institut Agama Islam NegeriSalatiga, Indonesia \\ Yahyaslamet54@yahoo.co.id
}

\begin{abstract}
This study aimed to determine the understanding of the Salatiga preaching institution to wasatiyah, the management of preaching in preaching wasatiyah, and the obstacles. The research used was a qualitative method. The results of this study indicated that the understanding of da'wah institutions to wasatiyah could be said to be linear. There was a tendency to equate moderate wasatiyah and a tendency to reject the radical, rigid, violent, and ghuluw religious methods and are felt to be lacking when rejecting the tafrìt or taqșir or jafä 'religion. The preaching management of the Da'wah preaching institution in Salatiga was still natural in nature and was a routine activity that had not approached the ideal management in the preaching of uncertainty in determining its vision and mission in preaching Wasatiyah. And the obstacles were the different perspectives of management, limited human resources, limited infrastructure and financial advice, ego and rigidity of some administrators
\end{abstract}

Keywords: Da'wah, wasatiyah, and management

\begin{abstract}
Abstrak
Penelitian ini bertujuan untuk mengetahui pemahaman lembaga dakwah Kota Salatiga terhadap wasatiyah, manajemen dakwahnya dalam mendakwahkan wasatiyah, dan hambatannya. Penelitian yang digunakan adalah metode kualitatif.Hasil penelitian ini menunjukkan bahwa pemahaman lembaga dakwah terhadap wasatiyah bisa dikatakan linear. Ada kecenderungan untuk menyamakan wasatiyahdengan moderat dan kecenderungan untuk menolak cara beragama yang radikal, kaku, keras, dan ghuluw dan dirasa kurang ketika menolak cara beragama tafrìt atau taqșir atau jafä'. Manajemen dakwah lembaga dakwah Kota Salatiga masih bersifat alami dan merupakan kegiatan rutinitas belum mendekati manajemen ideal dalam berdakwah kegamangan dalam menentukan visi misinya dalam mendakwahkan wasatiyah. Dan hambatannya ada perbedaan perspektif pengurus, keterbatasan SDM, keterbatasan sarana prasarana dan finansial, ego dan kekakuan sebagian pengurus
\end{abstract}

Kata Kunci : Dakwah, wasațiyah, dan manajemen 


\section{Pendahuluan}

Semua agama pada dasarnya mengajarkan kepada pemeluknya untuk hidup dalam kedaan damai. Bahkan agama hadir dan eksis untuk menyantuni dan menyelamatkan anak manusia, menunjukan jalan menuju kedamaian, ketentraman dan keselamatan, dan menghindarkan ketidakpastian, menyebarluaskan kasih sayang antar sesama manusia, menyucikan diri dari perbuatan-perbuatan buruk, tercela atau merusak dan lainnya dari peran agama (Azra, 1996: 182) dan agama pada dasarnya mempunyai faktor integrasi dan disintegrasi (Basyuni, 2006:5).

Ada semacam kekhawatiran dan kecemasan yang melanda kalangan masyarakat secara merata terhadap meningkatnya fanatisme yang pada akhirnya meningkat pula sikap keberagamaannya yang memicu sikap radikal dalam makna negatif dalam beragama. Munculnya radikalisme agama mungkin saja dipengaruhi oleh makin meningkatnya pemahaman terhadap dogma, dasar-dasar keyakinan dan peribadatan agama yang diyakininya secara sempit dan fanatis dan atau mungkin juga disebabkan oleh pemahaman yang tidak komprehensif terhadap ajaran agama tersebut.

Pada sisi lain, pemahaman yang tidak komprehensif terhadap ajaran agama dan pemahaman yang hanya ada dalam permukaan melahirkan iman yang tipis mudah diombang-ambing oleh berbagai macam keraguan dan spiritualitas yang kering. Yang paling ideal dan terbaik adalah sikap pertengahan antara dua sisi yang berseberangan dalam beragama. Sikap itu dikenal dalam Islam dengan wasat.

Wasatiyah umat Islam bersumber dari agamanya yaitu Islam yang mempunyai metode dan aturan yang wasat. Hal ini, memang, sangat pantas bagi umat Islam karena Islam adalah agama terakhir dan kehadirannya untuk seluruh umat manusia sampai hari kiamat sehingga umat ini menjadi pilihan dan adil karena mereka akan menjadi saksi 
atas perbuatan orang yang menyimpang dari kebenaran baik dalam kehidupan dunia maupun kehidupan akhirat. Argumen tersebut sangat tepat, karena jika predikat itu disematkan kepada umat agama lain yang risalahnya hanya bersifat temporal dan wilayahnya pun lokal. Dengan batasan dimensi waktu dan tempat, maka jika terjadi penyimpangan, solusi yang diberikan agama yang dibatasi oleh dua dimensi tersebut hanya bersifat sementara dan cocok untuk masanya, dan treatmen yang diberikan cukup hanya lawan dari keadaan yang ada. Sebagai contoh masyarakat yang terlalu cinta kepada keduniaan bisa diluruskan dengan cinta kepada keakhiratan dan yang terlalu cinta kepada materi diluruskan dengan cinta kepada immateri.

Wasatiyah Islam memang tidak perlu diragukan dan itu memang sudah melekat sejak dibawa oleh Nabi Muhammad Saw. Namun sekarang, kenyataan di lapangan kadang kurang ideal. Masyarakat muslim sekarang harus kemabali kepada wasatiyah Islam dan mau mengkaji kembali konsep wasatiyah agar tetap menjadi pengadil yang adil, lurus, terbaik, memberikan rasa aman, berkekuatan, dan bersatu di bawah nilai-nilai Ilahi.

Masyarakat muslim kadang terbagi menjadi dua kubu yang saling berseberangan, yang satu bersikap tertalu keras, berlebihan, maunya menang sendiri, mengangggap yang lain salah, dan tidak terbuka menerima pendapat pihak lain. Sementara yang satu lagi bersikap sangat terbuka, semua hal bisa dilihat dan dipandang dengan multi tafsir bagi mereka, memperbolehkan ijtihad dalam segala bidang agama, dan semua ajaran Islam layak untuk ditela'ah kembali dengan tidak mengindahkan nilai-nilai permanensi dan perubahan (al-Qardawi, 2011:35)

Manusia lemah untuk merealisasikan konsep wasatiyah dengan keterbatasan akal dan pengetahuannya dan ditambah pula adanya faktor-faktor kecenderungan dan kecintaan manusia terhadap keluarga, kelompok, bangsa dan lainnya. Yang sanggup mewujudkan konsep itu 
hanya Allah Swt. Oleh sebab itu, Islam menginginkan manusia untuk belajar dari keseimbangan alam semesta ini sehingga terefleksikan dalam kehidupan, pola pikir, sikap, dan tindakannya. Allah menegaskan dan mengingatkan setiap muslim agar selalu merenungkan Q.S al-Baqarah (2):143 agar tetap dalam keadaan wasat danmengajak yang lainnya melalui dakwah untuk tetap dan menjadi wasat.

\section{Permasalahan}

Rumusan masalah dalam penelitian ini adalah (1) Bagaimana pandangan lembaga dakwah kota Salatiga terhadap wasatiyah? (2) Bagaimana lembaga dakwah Kota Salatiga memanej program-programnya untuk menyebarluaskan nilai-nilai wasațiyah? (3) Faktor-faktor apa yang menjadi kendala dan pendorong bagi lembaga dakwah kota Salatiga dalam mewujudkan dakwah yang wasaț?

\section{Manajemen Dakwah}

Manajemen dakwah adalah terminologi yang terdiri dari dua kata, yaitu manajemen dan dakwah. Kedua kata ini berbeda dalam disiplin ilmunya. Manajemen adalah ilmu dan seni yang mengatur proses pemamfaatan sumber daya manusia secara efektif, dengan didukung oleh sumber-sumber lainnya dalam suatu organisasi untuk mencapai tujuan (Athoillah, 2010:14)

Manajemen, secara bahasa, memiliki makna ketatalaksanaan, tata pimpinan dan pengelolaan (Echol). Artinya manajemen adalah sebagai suatu proses yang diterapkan oleh seseorang atau organisasi dalam upaya koordinasi dalam mencapai suatu tujuan.

Sedangkan secara terminology, manajemen mempunyai banyak definisi yang dikemukakan oleh para ahli, diantaranya adalah: "The process of planing, organizing, leading, and controling the work of organi- 
zation members and of using all availeabel organizational resources to reach stated organizatonal goals" (James, 1997:7)

Dakwah, secara literal berarti dasar kecenderungan sesuatu yang disebabkan suara dan kata-kata (Warson, 1984: 58).Dakwahjuga berarti mencintai sesuatu atau mendekatkan diri pada sesuatu (ibn Faris, 1970: 328). Dari kata kerja دعا - يدعو ini terbentuk dua isim mashdar yaitu do'a yang berarti panggilan, seruan, do'a, permohonan, kutukan dan laknat (Ali, 1996:895) dan dakwah yang berarti ajakan, undangan, himbauan, permintaan, misi, propaganda (Ali, 1996: 896). Dakwahdiartikandengan memanggil, mengajak, mendorong, mengundang, dan menyeru (Amin, 1980: 13-15 dan Saleh, 1982: 6-7).

Dalam al-Qur'an, kata dakwah secara literal mempunyai beberapa arti yaitu mengharap dan berdo'a kepada Allah Swt seperti tertuang dalam Q.S al-Baqarah (2):186, memanggil dengan suara lantang seperti ada dalam Q.S al -Rum (30):25), dan mendorong orang untuk memeluk suatu keyakinan tertentu seperti dapat dilihat dalam Q.S al-Baqarah (2):22 (Amin, 1997:8-9)

Fadlhlullah (1997:11-12) menyatakan bahwa al-Qura'an memang kitab dakwah dengan bukti sebagai berikut;(1) al-Qur'an berisiajakan menyembah Allah dan mentaati Rasululllah, (2) al-Qur'an menganalisis faktor pendorong dan pelaksanaan dakwah. (3) Tujuan dakwah dan metodenya dan teknik pelaksanaannya diungkap oleh al-Qur'an. (4) alQur'an membina para da'i dengan menguatkan pribadi dan imannya agar tetap lurus di jalan-Nya. (5) al-Qur'an mengungkap tahapan dakwah sebagaimana tahapan dakwah Rasulullah. (6) al-Qur'an menyebutkan kedudukan dan arti penting dakwah dalam Islam dan keutamaan para pekakunya.

Secara etimologis, dakwah bisa didefinisikan sebagai proses memindahkan umat dari satu situasi ke situasi yang lain yang lebih baik 
(al Khuly, 1982: 8). Dakwah adalah suatu aktivitas yang mendorong manusia untuk memeluk Islam melalui cara yang bijaksana, dengan materi ajaran Islam, agar mereka mendapatkan kesejahteraan di dunia dan kebahagiaan di akhirat (Amin, 1980: 16). Dakwah juga bisa didefinisikan sebagai ishlāh, yaitu memperbaiki keadaan umat Islam atau proses memindahkan kepada situasi lebih baik dan memberi petunjuk kepada orang kafir agar mau masuk Islam. Dakwah merupakan suatu proses penyampaian, ajakan kepada orang lain agar mau memeluk, mempelajari dan mengamalkan ajaran agama secara sadar, sehingga menjadikan para audiens bangkit dan kembali ke potensi alaminya yaitu fitrah dan menjadikan mereka bahagia di dunia dan akhirat (Budiharjo, 2007:2). Dakwah adalah mengajak dan menyeru manusia secara umum agar mengakui Allah sebagai Tuhan yang harus disembah dan menjalani kehidupan mereka sesuai dengan ketentuan-ketentuan Allah yang tertuang di dalam al-Qur'an dan Sunah (Yani, 2005:1)

Dengan demikian, dakwah adalah segala aktifitas yang baik mengajak, menyeru, dan memanggil manusia baik yang belum Islam untuk memeluk Islam dan mengamalkannya dan yang sudah Islam untuk memahami dan mengamalkan ajaran Islam. Kegiatan tersebut bertujuan untuk meraih kebahagiaan dunia dan akhirat.

Al-Qur'an menyebut kalimat dakwah dengan berbagai macam bentuk derivasinya berulang kali sebanyak 219 kali dalam bentuk kata kerja dan kata benda. Pengulangan tersebut menunjukan betapa besar perhatian al-Qur'an kepada dakwah agar kehidupan manusia bisa lebih baik dari waktu ke waktu seiring dengan perubahan yang tidak terelakkan dalam segala bidang kehidupan.

Kalimat dakwah juga bisa bermakna mirip dengan kalimat tablig, amr ma'rūf dan nahi munkar, wasiyah, nasihah, khuṭbah, mau'izah, mujādalah, tażkirah atau inżār (Syam, 2007:4-6) 
Jika aktivitas dakwah dilaksanakan oleh lembaga dakwah sesuai dengan prinsip-prinsip manajemen, maka citraprofesional dalam dakwah akan terwujud dalam kehidupan masyarakat. Dengan demikian dakwah tidak hanya dimaknai sebagai kegiatan ibadah saja, akan tetapi ditafsirkan dan dipahami sebagai beberapa profesi. Inilah inti dari pengaturan secara manajerial organisasi dakwah. Aktivitas dakwah dikatakan berjalan efektif dan efesien apabila apa yang menjadi tujuannya benarbenar tercapai, dan dalam pencapaiannya membutuhkan beberapa pengorbanan yang wajar.

Manajemen dakwah yaitu sebuah pengaturan secara sistematis dan koordinatif dalam kegiatan atau aktivitas dakwah yang dimulai dari sebelum pelaksanaan sampai akhir dari kegiatan dakwah (Munir, 2009:16)

Manajemen merupakan salah satu dari kunci keberhasilan dari sebuah lembaga dalam meningkatkan dan memajukan baik secara kualitas maupun kuantitas. Manajemen merupakan proses perencanaan, pengorganisasian, pengoordinasian, dan pengontrolan sumber daya untuk mencapai sasaran secara efektif dan efisien.

Ini yang merupakan inti dari manajemen dakwah, yaitu sebuah pengaturan secara sistematik dan koordinatif dalam kegiatan atau aktifitas dakwah yang dimulai dari sebelum pelaksanaan sampai akhir dari kegiatan dakwah. Dalam kaitan ini fungsi manajemen dakwah berlangsung pada tataran dakwah itu sendiri. Dimana setiap aktivitas dakwah khususnya dalam skala organisasi atau lembaga untuk mencapai suatu tujuan dibutuhkan sebuah pengaturan atau manajemen yang baik, ruang lingkup kegiatan dakwah merupakan sarana atau alat pembantu pada aktivitas dakwah itu sendiri.

Adapun unsur-unsur manajerial yang minimal harus ada dan merupakan sebuah kesatuan yang utuh adalah takhțiț (Perencanaan 
Dakwah), Tanzīm (Pengorganisasian Dakwah), Tawjīh (Penggerakan Dakwah), dan Riqābah (Pengendalian Dakwah atau Evaluasi)

\section{Tujuan Manajemen Dakwah}

Tujuan manajemen adalah pencapaian suatu hasil yang ingin dicapai melalui proses manajemen. Tujuan tersebut selalu ditetapkan dalam suatu rencana, karena itu hendaknya tujuan itu bersifat jelas, realistis, dan cukup menantang berdasarkan analisis data, informasi, dan pemilihan dari alternatif-alternatif yang ada (Hasibuan, 2009:17)

Sedangkan tujuan dari dakwah adalah hasil akhir yang ingin dicapai dan diperoleh yaitu mencapai kebahagiaan dan kesejahteraan hidup di dunia dan di akhirat yang diridhai oleh Allah Swt (Saleh, 1986:21). Lebih rinci lagi, Munir (2009:87-91) menyatakan bahwa tujuan khusus dakwah adalah perumusan tujuan umum sebagai perincian dari pada tujuan dakwah itu sendiri. Sedangkan tujuan umumnya adalah mengubah perilaku sasaran agar mau menerima ajaran Islam dan menjalankannya dalam kehidupan sehari-hari, baik itu yang berkenaan dengan masalah individu, keluarga maupun masyarakat, supaya mendapatkan keberkahan dari Allah Swt.

Jadi, secara umum tujuan dan kegunaan manajemen dakwah adalah untuk memberikan arah dan tuntunan agar pelaksanaan dakwah dapat dilaksanakan secara professional dan proporsional.

\section{Makna Wasatiyah}

Wasatiyah terambil dari kata wasat yang secara literal bermakna pertengahan. Wasat yaitu berada pada posisi pertengahan (Warson, 1984: 1557). Al-Fairuz Abadi menyatakan bahwa Wasat berarti yang paling adil atau adil lagi terpilih (Abadi, 1995:622)

Dengan mengutip dari ibnu Faris, al-Shalabi (2001:13-14) menyatakan bahwa wasat berarti keadilan dan pertengahan sesuatu. 
Wasat berarti yang terbaik, yang adil dan lainnya. Dan dengan mengutip dari al-Tabari, beliau mengatakan bahwa wasat berarti al-'adl dan di kesempatan lain Wasat dinyatakan sebagai yang terbaik (al-Shalabi, 2001:18).

Kata wasaț ini juga berarti adil. Seseorang yang adil dalam memutuskan perkara adalah yang tidak berat sebelah, memutuskan sebuah perkara dengan hukum sebenarnya, dan memberikan hak kepada pemilik yang sesungguhya. Wasat juga berarti hal yang terbaik atau yang termulia. Ketiga makna tersebut terdapat dalam al-Qur'an dan hadits. Dalam al-Qur'an digunakan paling tidak ada lima ayat yang menyebutkan tentang wasat.

Abu Yusuf (2017:9) menyatakan lebih rinci tentang penggunaan kata wasat Pengertian wasat secara etimologi adalah adil, pertengahan, sesautu yang teradil, sedang dan tengah. Jika berbentuk kata sifat, maka wasat berarti terbaik, lebih utama, dan terbagus. Lebih lanjut beliau mengatakan bahwa kata wasat yang digunakandalam al-Qur'an dan Hadis mengahdirkan beberapa makna, yaitu:(1) Adil, (2) Baik, (3) Pertengahan antara tafrīt dan ifrāt seperti dalam firman Allah dalam Q.S. al-Baqarah (2):143. Ketiga makna itu sebagaimana beliaukutipdarilbnu Katsir dan al-Tabary dalam tafsirnya. (4) Terbaik dan tertinggi seperti surga Firdaus yang merupakan surga yang paling baik dan tertinggi derajatnya (Sahih Bukhori 2637 dan 6987), (5) Berada di tangah antara yang baik dan buruk (Q.S al-Maidah (5): 89), (6) Terbaik dan teladan, (7) Antara 2 ujung dan atau 2 pojok (Q.S al-Baqarah (2) 238. Sholat Wust $\bar{o}$ adalah sholat yang berada diantara 2 sholat Subuh dan Dzuhur dan 2 sholat yang lain yaitu Maghrib dan Isya'. (9) Tengah-tengah suatu tempat (Abu Yusuf, 2017:10-13)

Dalam beberapa tafsir al-Qur'an, al-Suyuthi misalnya mengatakan bahwa kata wasat adalah keadilan sebagaimana beliau kutip dari ibnu Jarir dari sahabat Abu Hurairoh dan Ibnu Abbas yang mengatakan bahwa 
wasat adalah Keadilan(al-Suyuthi, 1990:266).Beliaumelanjutkanbahwa kata yang tepatuntukumat Nabi Muhammad adalah wasaț sedangkan untuk Bani Israil adalah sabt (al-Suyuthi, 1990:266).

Al-Samarqandi (1993:164) juga mendukung dan menegaskan wasat adalah adilseperti dalam firman Allah yang lain awsațhum yang beliaumaknaidenganterbaik dan teradil, Nabi Muhammad adalah orang yang terbaik nasabnya dari Quraisy.Lain halnya dengan Muhammad Abduh dan Rasyid Ridla (Tth: 4) dalam al-Manarnya, beliau mengatakan bahwa wasat itu adalahhidayah Allah kepada yang Dia kehendaki, bahwa umat Islam adalah mendapat petunjuk Allah ke jalan lurus.Wasat adalah adil dan keterpilihan dan keterbaikan. Dia di tengah antara dua hal. Melebihkan atas yang dipinta dalam suatu urusan adalah ifrāt dan menguranginya adalah tafrìt dan taqșir $r$ Keduahaltersebutkeluar dari jalan lurus dan itu buruk dan tidak terpuji.Khiyār adalah syarat bagi seorang saksi yang memang harus mengetahui dua pihak yang bersengketa, dan adil adalah dalil yang menunjukan keterbaikan dan keterpilihan muslim dalam hal ini. Kemudian beliau melanjutkan bahwa Islam hadir berada diantara dua kelompok saat itu yaitu Yahudi dan kaum musyrik yang materialisme dan mementingkan materi di satu sisi dan di sisi lain ada Nasrani dan Shabi'in dan sebagian Hindu yang mementingkan rohani saja dan meninggalkan kelezatan dunia.

Kata wasat digunakan untuk 5 (lima) hal sebagai kesimpulan dari berbagai macam pendapat.(1) Bermakna yang terbaik, yang diutamakan, dan yang adil, (2) Bermakna yang berada di antara dua hal yang berlebihan.(3) Bermakna yang berada di antara dua hal yaitu kebaikan. (4) Bermakna yang berada di antara baik dan buruk. (5) Kadang digunakan untuk menunjukan yang berada di antara dua hal yang abstrak seperti di tengah rumah (al-Shalabi, 2001:18).

Secara terminologi,Yusuf al-Qardawi (2011:13) menyatakan bahwa al-Wasațiyah adalah tengah-tengah antara dua ujung atau pihak 
yang saling berhadapan atau berlawanan, salah satu pihak atau keduanya tidak mempengaruhinya, menolak untuk memihak salah satunya atau keduanya, dan tidak mengambil hak yang lebih dari batasannya dari dua pihak tersebut. Wasațiyah disebut juga al-Tawāzun (keseimbangan) dan al-I'tidāl (tegak lurus atau pertengahan)

Dalam kesempatan lain, al-Qardawi mengatakan bahwa al-Wasatiyah adalah mengambil jalan tengah dan seimabl antara 2 ujung yang saling berseberangan berlawanan dimana jalan itu tidak terpengaruh oleh salah satunya dan menolak salah satunya, jalan yang tidak salah satu dari 2 ujung tersebut mengambil haknya secara berlebih sehingga melampui yang lainnya (al-Qardawi, 1985:127)

Menurut Farid dalam al-Shalabi (2001:33) al-Wasatiyah adalah bekal yang ada pada umat Islam dari keadilan dan kebaikan agar menjadi saksi bagi seluruh umat manusia dan menegakan argumen kepada mereka, Kalimat ini tidak mesti harus berada di antara dua hal. Yang pasti bahwa wasat mesti harus memenuhi syarat yaitu kebaikan dan posisinya yang berada di antara dua hal (al-Shalabi, 2001:34)

Al-Wasatiyah adalah kesimbangan (balance), dan kesimbangan adalah keadilan sebagaimanan dalam firman Allah Q.S. al-Baqarah (2):143. Wasat dalam sesuatu adalah keseimbangan dalamberbagai aktifitas dan perbuatan. al-Wasatiyah merupakan usaha menyeimbangkan dan mengharmonikan antara banyak hal, antara tuntutan individu dan tuntutan masyarakat, antara amal dunia dan amal untuk akhirat (Quthub, 1982:28). Hampir para ulama berijma' bahwa Wasatiyah keadilan, karena keadilan itu berada di antara 2 (dua) hal yang tidak baik atau tidak terpuji (ekstrim kanan dan ekstrim kiri) dan kewasatan Islam ada di antara tafrīt dan ifrāt (Abu Yusuf, 2017:14) 


\section{Metode Penelitian}

Penelitian yang digunakan ini bersifat deskriptif dan menggunakan metode kualitatif dengan mengembangkan kombinasi model etnometodologi dan metode partisipatoris. Noeng Muhadjir (1996), mendefiniskan etnometodologi sebagai studi kualitatif yang mempelajari bagaimana perilku religi dideskripsikan sebagaimana adanya. Etnometodologi berupaya untuk menjelaskan dan mengambarkan aktifitas mereka sendiri. Metode partisipatoris merupakan proses pengumpulan data yang melibatkan kerjasama aktif antara pengumpul data dan responden. Pertanyaan-pertanyaan umumnya tidak dirancang secara baku, melainkan hanya garis-garis besarnya saja. Topik-topik pertanyaan bahkan dapat muncul dan berkembang berdasarkan tanya jawab dengan informan.

Lokasi penelitian adalah kota Salatigadan objek penelitian ini adalah pemahaman lembaga dakwah kota Salatiga terhadap dakwah yang wasat dan aktifitas dakwah dan kendala dan pendorong dalam mewujudkannya. Subyek penelitian adalah pengurus lembaga dakwah di Kota Salatiga, baik yang ada di organisasi sosial kemasyarakatan Islam, masjid, dan majlis taklim. Pengutamaan organisasi sosial kemasyarakatan Islam sebagai subyek penelitian didasarkan pada perannya yang besar dan dalam banyak kasus, masjid dan majlis taklim tidak lepas dari pengurus organisasi tersebut.

\section{Pandangan Lembaga Dakwah Terhadap Wasatiyah}

Pemahaman lembaga dakwah Kota Salatiga terhadap Wasatiyah bisa dikatakan sejajar lurus dengan kebijakan organisasi kemasyarakatan Islam yang menjadi tempat naungan dari para pengurus lembaga dakwah tersebut. Mereka yang berafiliasi kepada Nahdlatul Ulama mengatakan bahwa Wasatiyahbermakna pertengahan, keadilan,dan keseimbangan. Sementara mereka yang berafiliasi ke Muhammadiyah menyatakan bahwa dalam Wasatiyah ada makna berkemajuan. 
Pemahaman semacam itu cukup memadahi terhadap konsep Wasatiyah Islam, namun ada kecenderungan untuk menjauh dan menolak Islam yang kaku, keras, dan ghuluw dan dirasa kurang ketika menolak tafrịt atau taqșìr atau jafā'. Padahal Wasatiyah adalah bersifat bainiyah, berada di tengah dua kubu yang saling berlawanan tanpa cenderung kepada salah satunya.

Tafrịt atau taqșìr atau jafä' pada kenyataan di lapangan adalah sebuah fenomena yang umum kita dapatkan di Kota Salatiga. Sebab pemahaman sebagian umat Islam terhadap ajaran Islam masih dirasa belum memadahi, belum ditambah lagi dalam ranah praktik dan pelaksanaan ajaran agama. Hal itu berdasarkan pantauan peneliti selama membina beberapa masjid dan majlis taklim.

Wasatiyah adalah pertengahan dan keseimbangan dalam menentukan sikap keberagamaan dan amaliyah ubudiyahnya. Dia berada diantara keberagamaan yang berlebihan dan melampui batas yang dikenal dengan istilah ghuluw atau ifrāt dan keberagamaan yang meremehkan, gegabah, ceroboh, dan jauh dari nilai ideal secara teoritis dan praktis dalam beragama yang lazimnya dikenal dengan istilah tafrīt atau taqșīr atau jafā'.

Al-Shalabi (2001:46) memilih diantara 2 pendapat ulama tentang ghuluw yaitu pendapat ibnu Taimiyah yang mengatakan bahwa ghuluw adalah melampui batasan, dan Ibnu Hajar yang mengatatakan bahwa ghuluw adalah berlebihan dalam sesuatu dan terlalu ketat dan keras di dalamnya dengan melampui batasannya.

Ukuran dan standar ghuluw adalah melampui batasan yang Allah perintahkan dan melampui batas yang dilarang. Ghuluw adalah melampui batasan dalam hal yang disyariatkan hal itu terjadi dengan menambah atau berlebihan sehingga melampui batasan sehingga mengeluarkannya dari kehendak dan maksud yang ditetapkan oleh Allah. Setelah menilik 
makna-makna kata ifrāt, al-Shalabi (2001:51) menyimpulkan bahwa ifrāt adalah melampui batas, dan melebihi kadar yang diminta dalam beragama.

Sedangkan kata tafrìt atau taqșìr atau jafä' adalah lawan dari ghuluw atau ifrāt. Tafrīt adalah meninggalkan sesuatu dari ajaran agama, menjauhkan diri darinya, dan juga disebut sebagai akhlak yang tidak baik sedangkan jafä' adalah cara beragama yang berangkat dari menganggap agama itu mudah dan meremehkan ajarannya (al-Shalabi, 2001:57).

\section{Gambaran Wasatiyah}

Wastiyah Islam tergambar dalam keseimbangan akidah, keseimbangan ibadah dan syiar, keseimbangan akhlak, keseimbangan jasmani dan ruhani, keseimbangan perundangan, dan keseimbangan antara individu dan masyarakat.

Menggambarkan Wasatiyah bisa dilakukan dengan menetapkan indikator-indikatornya yang harus merujuk kepada Islam itu sendiri karena Wasatiyah seseorang atau lembaga pada hakikatnya bersumber dari Islam dengan dua sumber utamanya yaitu al-Qur'an dan Hadis. Kedua sumber inilah yang menjadi barometer penilaian bagi wasat atau tidaknya seseorang atau lembaga.

al-Shalabi contohnya, ketika mengatakan bahwa ciri yang melekat pada Wasatiyah adalah keterpilihan dan keterbaikan, maka pada hakikatnya merujuk pada Q.S Ali Imron (3) ayat 103 dan 110, keadilan merujuk kepada Q.S al-Baqarah (2) ayat 143, mudah dan tidak sulit merujuk kepada Q.S. al-Baqarah (2) ayat 286, hikmah (bijak) merujuk kepada Q.S. al-Nahl (16) ayat 125, istiqamah merujuk kepada Q.s alFatihah (1) ayat 5, dan bainiyah merujuk kepada Q.S al-Qashash (28) ayat 77 (al-Shalabi, 2001:68)

Berdasarkan penjelasan di atas, maka indikator kewasatan seseorang atau lembaga adalah jika dia menjadi muslim yang berbuat 
kebaikan dengan cara terbaik, muslim yang adil yang menempatkan sesuatu pada tempatnya, adil bagi diri sendiri dan orang lain, muslim yang mudah hidupnya dan berusaha memudahkan orang lain, muslim yang mempunyai hikmah yang meletakan sesuatu pada tempatnya. (alZaid, Tth: 24)

Menggambarkan wasațiyah yaitu menggambarkan sikap dan cara beragama yang tidak melampui batasan teks-teks syariat yang ada dalam al-Qur'an dan Hadis Nabi Muhammad Saw (Ibnu Taimiyah,Tth: 362). Muslim yang berpegang teguh pada ajaran al-Qur'an dan Sunah, serta mempunyai keinginan yang keras dalam mentaati Allah dan rasulNya, dan menjauhi segala larangan-Nya bukan ghuluw (al-Qulati, 1426:133). Sedangkan muslim yang melampui batasan dalam hal yang disyariatkan dengan menambah atau berlebihan sehingga melampui batasan sehingga mengeluarkannya dari kehendak dan maksud yang ditetapkan oleh Allah adalah ghuluw (al-Shalabi, 2011: 46).

\section{Karakter Wasatiyah}

Islam adalah agama Allah yang memang diciptakan untuk menjadi agama yang terbaik, terpilih, dan adil (Q.S. al-Baqarah (2):143). Islam adalah risalah Allah yang dibawa oleh nabi terakhir, sebagai risalah terakhir, dan diperuntukan untuk segenap alam, bersifat universal dan abadi untuk umat manusia sampai hari kiamat nanti. Dengan demikian, Islam relevan dan cocok untuk semua masa dan semua tempat. Islam adalah agama ciptaan Allah Swt yang bersifat mondial untuk seluruh alam dengan beberapa alasan diantaranya adalah; (1) Tidak khusus untuk satu golongan tertentu. (2) Tidak khusus untuk satu tempat dan lingkungan tertentu, (3) Cocok untuk segala tempat dan zaman. (4) Bersifat fitri dan manusiawi karena menganggap manusia sebagai manusia. (5) Bersifat abadi sampai hari kiamat. (Shaqr. 1998:10-11) 
Keistimewaan Islam terletak dalam 5 hal yaitu; (1) Dari sisi sumbernya Islam berasal dari Allah SWT, Islam bersumber dari kalam Allah baik secara lafadz atau makna (al-Qur'an) dan secara lafadz tidak dengan makna (Hadis nabi). Dampak dari itu adalah bahwa Islam sempurna dan lepas dari kekurangan karena melihat pembuatnya Yang Maha Sempurna. Dampak lain adalah bahwa Islam beruntung mendapatkan kharisma besar dari kaum mukmin meski ada kekuasaan lain. Negara umpamanya juga tunduk kepada Islam. (2) Dari segi hubungan yang diaturnya dan hukum yang diaturnya, Islam bersifat komprehensif. Islam menyangkut kehidupan dan sikap manusia dalam segala seginya. Sifat ini adalah tetap dan riil ada dalam Islam. (3) Dari segi personal yang membawanya, Islam berlaku umum.Islam sudah dikenal dipruntukan umtuk semua umat manusia dan tidak khusus untuk suatu kelompok tertentu. Keumumannya tidak terbatas oleh ruang dan waktu. (4) Dari segi upah dan ganjaran bagi yang menyalahinya atau yang mengikutinya, Islam mempunyai pahala dan ganjaran duniawi dan ukhrawi.Pada dasarnya hukuman dalam Islam adalah diakhirat, akan tetapi karena demi ketertiban masyrakat dan demi terjaminnya hakhak kehidupan mereka maka ada sanksi duniawinya.Dari segi kecenderungannya kepada yang ideal atau yang faktual, Islam bersifat ideal faktual. (5) Islam sangat semangat untuk membawa manusia ke derajat paling tinggi atau ideal, akan tetapi dia juga mengakui tabiat manusia dan realitasnya sehingga Islampun harus realistis (Zaidan, 2002: 45- 71)

Kewasatan Islam itu sendiri yang sebenarnya harus menjadi kakakter kewasatan umatnya. Ciri-ciri Islam yang ideal itulah sebenarnya yang harus menjadi rujukan dalam mengidentifikasi karakter dan ciri yang harus ada dalam diri umat yang diinginkan oleh lembaga dakwah. 


\section{Dakwah Wasațiyah}

Secara teori, Wasațiyah dipahami dengan baik oleh lembaga dakwah meskipun belum semua karakter dan indikator belum terwujud. Dan itu memang membutuhkan waktu dan usaha yang keras. Yang jelas, Wasatiyah merupakan cita-cita yang ingin diwujudkan oleh lembaga dakwah dalam kegiatan dakwah.

al-Shalabi (2001:16) menyatakan bahwa dakwah yang wasat mempunyai beberapa kriteria yaitu rasional, dilakukan dengan sadar dan bijak, memamahmi kejiwaan audience, mengetahui kesesuaian metode yang digunakan, merealisasikan tujuan Ilahi, dilakukan dengan bekerja sama, mempersiapkan jiwa untuk bisa menerima dakwah, memperhatikan sarana dan prasarana, memperhatikan situasi kondisi audience muslim atau bukan, ketersediaan teladan baik, kesesuaian perkataan dan perbuatan, tabah dan gigih, sabar dan lembut, semangat tidak putus asa, bersenjatakan ilmu pengetahuan yang cukup, memperhatikan keaslian dan kekinian, memahami tabiat bangsa, suku, dan golongan, berbekal pengetahuan tentang agama lain, adat, dan kebudayaan yang biasa dilakukan.

Dalam konsep al-Zaid (Tth:24), dakwah yang seperti tersebut di atas disebut dakwah bi al-hikmah yang memerintah dan menganjurkan untuk mengetahui dan memahami, berusaha untuk menggapai kenbenaran dan ketepatan dalam ucapan dan perbuatan, meletakan sesuatu pada tempatnya, pengetahuan dan kesadaran dan mengharagai sikap dan kondisi, berinteraksi dengan kenyataan dengan berkesinambungan dan produktif, tidak boleh keluar dari metode kebenaran yang jelas rambu-rambunya dalam al-Qur'an dan Hadis, bersifat universal, tidak kaku dan kondisoanal.

Dakwah Wasatiyah adalah dakwah yang dilakukan oleh da'i atau lembaga dakwah yang wasat dengan cara dan metode yang wasaț dan materi yang wasat, serta bertujuan untuk membentuk umat yang wasat pula. 


\section{Simpulan}

Pemahaman lembaga dakwah Kota Salatiga terhadap Wasatiyah bisa dikatakan linear dengan kebijakan organisasi kemasyarakatan Islam yang menjadi tempat naungan dari para pengurus lembaga dakwah tersebut. Mereka yang berafiliasi kepada Nahdlatul Ulama mengatakan bahwa Wasatiyah bermakna pertengahan, keadilan, dan keseimbangan. Sementara mereka yang berafiliasi ke Muhammadiyah menyatakan bahwa dalam Wasatiyah ada makna berkemajuan dan begitu juga dengan yang berafiliasi kepada organisasi lain. Pemahaman semacam itu cukup memadahi, namun jika dicermati ada kecenderungan untuk menolak Islam yang kaku, keras, dan ghuluw dan dirasa kurang ketika menolak tafrīt atau taqșīr atau jafā' padahal Wasatiyah adalah bersifat bainiyah, berada di tengah dua kubu yang saling berlawanan tanpa cenderung kepada salah satunya. Secara umum, lembaga dakwah Kota Salatiga menganggap Wasatiyah adalah moderat padahal faktanya ada perbedaan antara keduanya.Secara teori, Wasatiyah dipahami dengan baik oleh lembaga dakwah meskipun belum semua karakter dan indikator belum terwujudkarenabutuhwaktu dan usahayang kerasuntukmewujudkannya. Yang jelas, Wasatiyah merupakan cita-cita yang ingin diwujudkan oleh lembaga dakwah dalam kegiatan dakwahnya.

Lembaga dakwah Kota Salatiga merencanakan kegiatan dakwahnya secara alami dan masih bersifat rutinitas. Ada kegamangan dalam mengungkapkan visi dakwah dan misi yang merupakan usaha dan upaya untuk mewujudkan visi. Strategi yang digunakan untuk mencapai visi misi lembaga ada yang harus seperti keteladanan dan ada pula yang agak keras seperti menghadirkan nara sumber yang berbeda madzhab dengan jama'ah secara umum.

Organisasi lembaga dakwah Kota Salatiga beranggotakan masyarakat sekitar lembaga yang perekrutannya berdasarkan ketokohan dan 
info jama'ah, serta dialokasikan berdasarkan keahlian yang dimiliki oleh anggota. Adapun untuk perekrutan da'i, selain berdasarkan pertimbangan di atas, juga berdasarkan info da'i yang lebih berpengalaman dan wasat. Lain halnya dengan lembaga yang bersifat lintas sektoral, maka kepengurusan dipilih berdasarkan ketokohan dan keaktifan.

Dalam fungsi pengendalian, lembaga dakwah Kota Salatiga sudah melakukan fungsinya dengan baik. Dalam fungsi sebagai evaluator, lembaga dakwah menggunakan cara yang sarat dengan nilai-nilai wasat iyah seperti pendekatan persuasif, namun ada juga yang menggunakan teguran, pemanggilan langsung, dan mempertemukan da'i dengan jama'ah dan mengkonfrontasikan secara langsung yang semua itu kurang sesuai dengan semangat wasatiyah.

Hambatan dan kendala internal yang lembaga dakwah hadapi dalam mendakwahkan Islam yang wasat adalah perbedaan perspektif pengurus dalam memandang sesuatu, keterbatasan SDM dan da'i dalam manajemen dan wawasan keilmuan keislaman, keterbatasan sumber daya lembaga dari sarana dan prasarana serta finansial -meskiada yang sudah baik, ego dan kekakuan sebagian pengurus dan da'i yang masih memaksakan misinya sendiri.Ada lembaga dakwah yang mampu mengeliminir perbedaan seraya menyatukan langkah meski berbedabeda madzhab fiqhnya.

Sedangkan hambatan dan kendala eksternal yang rata-rata dihadapi oleh lembaga dakwah dalam mendakwahkan Islam yang wasat adalah masyarakat kurang memahami arti sebenarnya dari wasatiyah sehingga kurang mendukung dan kurang terbuka pada wasatiyah. Hambatan lain adalah sebagian da'i yang cenderung agak keras yang mengusung tema selain wasațiyah.

Ada lembaga yang mengatasi hambatan di atas dengan mengambil kaidah-kaidah dalam al-Qur'an dan Sunnah tentang makna wasat dan 
mensosialisasikannya kepada masyarakat dan mengharmonikan antar da'i untuk menuju satu langkah dan satu tujuan dengan memanfaatkan lembaga perguruan tinggi Islam di Kota Salatiga.

\section{DaftarPustaka}

Abadi, Majdudin Muhammad bin Ya'qub al-Fairuz. 1995/1415. al-Qāmūs al-Muhit. Libanon: Dar al-Fikr.

Abu Yusuf, Amali al-Sayid Hasan Ali. Tth. al-Wasațiyah Fī al-Islām Dirāsah

Fi Dalālatu al-Naṣ al-Qur'āni Wa al-Hadīs al-Nabawi al-Syarīf.

Ali Muhammad Muhammad al-Shalabi.2001. al-Wasațiyah Fī al-Qur'ān al-Karìm, Kairo: Maktabah al-Tabi'in. Cet 1

Ali, Atabik. 1996. Kamus Kontemporer Arab-Indonesia. Yogyakarta: Yayasan Ali Maksum Pondok Pesantren Krapyak.

al-Khuly. 1982. Tadzkiratu al-Du'āt, Kairo Mesir, Penerbit Daar al Qalam al-Qardāwi, Yusuf. 2011. Kalimāt Fī al-Wasațiyah al-Islāmiyah Wa Ma'ālimihā, Kairo:Dar al-Syurūq, Cet.3

al-Qardlawi, Yusuf. 1983/1404. al-Khashais al-'ammah Li al-Islam. Beirut:al- Risalah.Cet II

al-Qardlawi, Yusuf. Tth. al-Șahwah al-Islāmiyah.Baina al-Juhūd Wa alTațarruf. Beirut:al-Risalah

al-Qulati, Sami bin Ali. 1426. Dzahiratl al-ghuluw Fi al-Din-Dirasah Wa Tahlil.Majalah Universitas Thaibah. Al-uulm al-Tarbawiyah. Edisi 2 al-Samaqandi, Abu Laits Nashr bin Muhammad bin Ahmad bin Ibrahim. 1993/1413. Tafir al-Samarqandi.Beirut: Dar al-Kutub al-Ilmiyah. Juz 1

al-Suyuthi, Jalalulddin binAbdurrahman bin Abu Bakar. 1990/1411. alDurru al- Mantsur Fi al-Tafir al-Ma'tsur..Beirut:Dal al-Kutub alIlmiyah. Juz 1 
Al-Zaid, Zaid bin Abdul Karim. Tth. al-Hikmah Fīal-Da'wah Ilā Allāh Ta'rīf Wa Tatbìq. Bierut:Dar al-'Asimah.

Amin, Masyhur. 1980. Metode Dakwah Islam, Yogyakarta: PT Sumbangsih Azra, Azyumardi.1996.Pergolakan politik Islam dari fundamentalisme hingga post moderniusme, Jakarta:Paramadina

Basyuni, Maftuh. 2006. Kebijakan Dan Strategi Kerukunan Umat Beragama, Jakarta: DEPAG

Budihardjo. 2007. Dakwah dan pengentasan kemiskinan.Yogyakarta: Sumbangsih Pemikiran

Fadlhlullah, Muhammad Husain. 1997. Uslub al-Da'wah Fi al-Qur'an. Metodologi Dakwah dalam al-Qur'an. Terjemah Qasim Tamama Ahmad. Jakarta:Lentera.

Hasibuan, Malayu. 2009. Manajemen Dasar Pengertian dan Masalah, Jakarta:Bumi Aksara,Cet.8

Muhadjir, Noeng. 2000. Metodologi Penelitian Kualitatif. Yogyakarta: Rake Sarasin

Munawir, Ahmad Warson. 1984. Kamus al-Munawir Arab Indonesia Terlengkap. Yogyakarta: Yayasan Ali Maksum Pondok Pesantren Krapyak.

Munir M. 2009. Manajemen Dakwah. Jakarta: Rahmat Semesta

Quthub, Muhammad. 1982/1402. Manjahj al-Tarbiyah al-Islamiyah. Kairo: Dar al-Syuruq. Cet. 6 Jilid 1

Saleh, Abdul Rosyad, 1982. Manajemen Dakwah, Jakarta, PT Bulan Bintang. . 1986. Manajemen Dakwah. Jakarta: Bulan Bintang

Shaqr, Athiyah. 1998/1408. al-Dīn al-'̄Alami Wa Manhaj al-Da'wah Ilaih. Kairo: Majma' al-Buhuts al-Islamiyah. Tahun ke 18 buku kelima 
Stoner, James A.F dkk. 1995. Management. New Jersey:Prentice Hall.Sixt Edition

Syam dkk. 2007. Manajemen Dakwah, Dakwah dengan Tulisan Sebuah Peluang. Yogyakarta:Panji Pustaka

Yani, Ahmad. 2005. Bekal Menjadi Khotib dan Mubalig. Jakarta:Gema Insani Press

Zaidan, Abdul Karim. 2002/1423. Usus al-Da'wah.Beirut:Muassasah alRisalah. 